\title{
BOGANMELDELSER
}

Jocelyn M. Pollock: Ethics and Crime and Justice, Dilemmas and Decisions. 3. udg. West/Wadsworth, 1998.

I forordet til tredjeudgaven af bogen Ethics in Crime and Justice: Dilemmas and Decisions reflekterer Jocelyn M. Pollock nøje over etikkens stadigt voksende betydning for strafferetsplejen såvel i media som i de akademiske miljøer. Hendes bog, hvis primære formål er oplysning af studenter og andre interesserede, er et interessant svar på behovet for akademisk viden på dette felt.

I tredjeudgaven har Pollock med succes indført, hvad hun kalder 'pædagogiske værktøjer' for at hjælpe studenterne med at forstå og huske de forskellige etiske emner, som præsenteres. Hvert kapitel begynder således med fremsættelsen af afgrænsede og som oftest velformulerede 'formål', som tages under behandling i kapitlet. Bogen forsyner også lærere i emnet med 'kapiteloversigter' for at hjælpe med at skabe sammenhæng mellem de enkelte kapitler. Andre og nyskabende måder at illustrere undervisningen på er 'spørgesskemaer', debatspørgsmål eller hjælp til gennemtænkning og analyse af relevante emner.

Bogen balancerer på en god måde mellem på den ene side emner, som er baseret på en normativ vurdering af relevante spørgsmål, som kan henregnes til lovens moralske underbygning, og på den anden side citater, som tjener til empirisk undersøgelse af emnet. Endvidere er bogen med heldig hånd opbygget med henblik på at guide læseren gennem et ganske svært tilgængeligt felt af indbyrdes sammenhængende emner med fælles undertemaer. Således begynder bogen med en indførelse i de vigtigste argumenter for vigtigheden af at studere etik i strafferetsplejen og orienterer om fagterminologien på området. Derefter fortsættes med diskussion af og sammenkædning af temaer og teorier i de vigtigste etiske systemer med relevante emner i strafferetsplejen.

I kapitel 4 diskuterer Pollock sammensatte, men illustrerende dele af retsteorien, som vedrører oprindelse og bestanddele af retsbegrebet og dikotomien mellem materiel og processuel retfærdighed. Meningen med dette og de første tre kapitler er tydeligvis at skabe en klar og koncis begrebsmæssig baggrund for de følgende materielle diskussioner af retsudøvelsens etiske problemer i temmelig bred betydning (kapitlerne 5-11). En bemærkning er her på sin plads. Pollock begynder med at fastslå, at "underlying theme will be that the ends of law and justice are different, perhaps even at times contradictory ... [1] egal rights may be different than moral rights, rights may be different than needs, and needs may not be protected under either the law or some definitions of justice' (s. 86). Denne påstand er tydeligvis sand. Men det er muligt at rette overbevisende kritik mod Pollock for ikke at kvalificere denne påstand ved at citere forskning, som har til formål at argumentere for rettens og moralitetens convergens, idet moralitet her er synonym med retfærdighedsbegrebet.

Pollocks bog har klart til formål at give studerende af de omhandlede temaer et generelt og pragmatisk overblik over fremtrædende områder af ret og moral. Bogen opfylder dette formål. Følgelig besidder den ikke den tilstrækkelige dybde eller originalitet i materien til nødvendigvis at tjene videnskabelige og akademiske behov hos personer, som beskæftiger sig med disse emner. Det må dog understreges, at Pollock ikke stræber efter at tilfredsstille det akademiske samfunds intellektuelle appetit. Tværtimod fors $\emptyset$ ger hun med succes at give studenter og andre interesserede muligheden for at gøre sig bekendt med interessante områder af strafferet og etik.

Robert R. Spano

Det islandske Alting 
Tyge Krogh: Det store natmandskomplot. En historie om 1700-tallets kriminelle underverden. Samleren forlag, Viborg 2000. 187s.

I 1747 ble en bonde funnet død like ved Kalundborg på Sjælland. Mistankene om at han var blitt drept, ble fort sterke, og de rettet seg snart mot byens nattmenn. De ble satt i arrest, etter hvert sammen med stadig flere av sine venner og slektninger; det var et helt miljø som ble forfulgt og straffet meget strengt - til dels med døden. Men de ble ikke dømt for drapet på bonden: Dødsfallet forble uoppklart; kanskje hadde det virkelig vært en ulykke. Imidlertid hadde den opprinnelige drapsmistanken forløst mye dypt og gammelt nag og angst og fiendskap mellom nattmennene og deres familier på den ene siden og Kalundborgs borgere på den andre. Slik kom det for dagen en mengde andre anklager mot nattmannsfolket om vold, trusler og tyverier. Til sammen var anklagene mange og alvorlige nok til å drive en hel liten kultur i undergangen.

Tyge Kroghs Det store natmandskomplot ruller opp denne store og merkelige rettssaken, og gjenforteller den lett og med sval eleganse. Her făr vi vite mye fascinerende om nattmennene, som var noe bortimot en kaste av urene i en forholdsvis moderne bykultur. De feide skorsteiner, tømte latriner og kagger, flådde og gravde ned døde dyr og bisto bøddelen ved henrettelser og pinsler: oppgaver som knyttet seg til det vanærende, til tilværelsens mørke og natt - derav navnet på de menneskene som utførte dem. Arbeidsoppgavenes urenhet gjorde nattmennene til de laveste blant de lave og stengte dem ute fra det alminnelige sosiale fellesskap av byborgere og bønder. De bodde for seg selv i byens periferi og levde sine egne, skitne liv.

Alt dette vet vi, i og for seg, også fra Norge, uten at det er blitt skrevet så mye om det. Selv på 1970-tallet, da jeg var en gutt i gaten i Bergen, kalte vi hverandre "kaggetømmer" når vi kjeklet, og $\mathrm{i}$ de fleste byer med en viss historie finner vi stedsnavn som forteller at stedene har vært sosialt og kulturelt urene. Men det enkle og oppslukende spørsmålet Krogh svarer på i sin lille bok, er hvordan et slikt system kunne fungere og hva det gjorde med folk i det daglige. For i all sin urenhet og sin urørbarhet fylte nattmennene funksjoner som samfunnet rundt dem ikke kunne greie seg uten, samtidig som de selv var avhengige av omgivelser som ikke ville komme nær dem. Denne kompliserte relasjonen ga opphav til en mengde praktiske problemer. Hva gjorde man for eksempel når nattmennenes kvinner skulle føde og trengte hjelp - samtidig som det i det hele tatt å komme nær dem var tabu? Da stilte alle byens fruer opp, forteller Krogh, en for alle og alle for en, slik at kontakten ikke skulle være stigmatiserende for en enkelt, og de gikk i prosesjon til nattmannshuset: et fascinerende lite glimt av en kultur som med ett blir rituell og arkaisk på fremmede måter.

På den annen side satte utst $\varnothing$ telsen og urenheten nattmennene i stand til å hundse og trakassere sine omgivelser i en grad som ville vært umulig for alle andre. Den skitne oppgaven det var å spore opp og flå døde dyr, åpnet for eksempel muligheten til å slakte for fote og siden fråtse i kjøtt midt blant fattige naboer. Utstøtelsen i mørket ga ly mot innsyn, og urenheten skremte bort de fleste borgere fra eventuelle konfrontasjoner. Slik kunne nattmennene herje nesten som de ville i mørket. Helt, altså, til grensen ble nådd da en bonde ble funnet død - paradoksalt nok uten at de ellers farlige nattmennene later til å ha hatt noen skyld. For en gangs skyld.

Alt dette forteller Krogh om, knapt og usentimentalt, men i stor detalj. Og han er velsignet lite stringent. Forunderlige bihistorier gis mye plass når de dukker opp, og de er alltid bryet verdt å følge. I tillegg bruker han lang tid på å avdekke en mulig utenfor- 
liggende årsak til at det blir satt $\mathrm{i}$ gang en ren heksejakt mot nattmennene akkurat der og da: Det kan ha hatt å gjøre med den lokale godsforvalterens personlige behov for en kampsak. Også dette er en historie som forteller oss mye vi ikke visste om maktrelasjoner i det dansk-norske 1700-tallet, en periode som er merkelig lite utforsket. Så når vi endelig kommer til beretningens grufulle slutt, har vi beveget oss høyt og lavt - og dypt - i en fremmed kultur. Og vi har knapt vært utenfor Kalundborg.

Slik føyer Det store natmandskomplot seg inn i en "mikrohistorisk" tradisjon som omfatter klassikere som Emanuel Le Roy Laduries Montaillou og Carlo Ginzburgs Osten og markene. Den deler disse bøkenes leservennlighet, og materialet den presenterer er på sett og vis like forbløffende som deres. Men Krogh deler ikke riktig Laduries og Ginzburgs storøyde åpenhet i møtet med fortidens annerledeshet. Når han presses av materialet, når det virkelig utfordrer ham til å strekke seg i sine beskrivelser og fortolkninger, blir han blek og trekker seg bort. Ett av flere eksempler finner vi i en av hans sidehistorier, som handler om en tidligere vel ansett borger som faller selsomt og avgrunnsdypt etter å ha løyet grovt og offentlig. For den ene synden, løgnen, trekker andre med seg: Denne mannen, som lenge levde et normalt liv og hadde en viss makt, endte på skafottet etter at naboene hans så ham "stå bag en hoppe og have sex med den". Men "have sex med den" - det er en beskrivelse som ikke er i nærheten av å gripe det ufattelige, det metafysisk uhyrlige i det naboene så. Mannen hadde ikke sex med en ku: Han truet hele verdensordenen. I tillegg, selvsagt, kommer det at selve ordvalget "hadde sex med" er en anakronisme når det henlegges til midten av 1700-tallet. Det har vi lært av Foucault.

Krogh har ganske sikkert også lest Foucault, men han viser det ikke. Dette er min andre innvending, i tillegg til den lille skuffelsen over at Krogh ikke virkelig tar spranget ut i en fortolkende historisk antropologi. Det vil si: Jeg savner ikke Foucault, i og for seg. Men i en bok som Det store natmandskomplot, som har så stort formidlingspotensial, $\emptyset n$ sker jeg meg ikke bare formidling av et stykke fortid, men også av noe av den historiske litteraturen. Det er en styrke ved teksten at den forteller så rent og ledig, men den har et ganske anselig noteapparat med god plass til langt flere litteraturhenvisninger enn de som finnes. Nesten alle noter er henvisninger til arkivmaterialet. Dermed gir ikke Krogh noen særlig hjelp til interesserte lesere som ønsker å lese mer: De ledes til arkivene eller til gammel og etter hvert perifer litteratur. Med et litt åpnere blikk for perspektivene i sin case ville Krogh kunne ført slike lesere langt inn i den nye, internasjonale kulturhistorien, hvor det skjer så mye spennende.

Men spennende er sannelig også Det store natmandskomplot, og jeg har lest boken med stor begeistring og forbløffelse. Mest av alt er han kanskje likevel en briljant arkivar: Arbeidet som ligger bak denne unnselige boken må være enormt, og kildene åpner seg da også tillitsfullt mot Tyge Krogh. Kanskje ville han bli en enda mer slående historiker hvis han ikke hadde tatt så forsiktig i disse kildene. På den annen side: Hans sjenanse som fortolker er kanskje nettopp det som får meg til å føle at jeg har vært usynlig tilskuer til en fortid jeg tidligere bare så vidt har visst om.

\section{Erling Sandmo}

Universitetet i Oslo 
Janne Flyghed (red.).: Brottsbekämpning - mellan effektivitet och integritet: kriminologiska perspektiv på polismetoder och personlig integritet. Lund: Studentlitteratur, 2000. Et sentralt politisk virkemiddel i kampen mot kriminalitet, har i den seneste tiden vært å gi politiet økt mulighet til å overvåke mulige kriminelle. For eksempel har det i Norge vært en utbredt enighet, både på Stortinget og $\mathrm{i}$ offentligheten, om at dette er nødvendige trygghetsskapende tiltak for å aktivt gjøre noe med kriminalitetsomfanget. Men det at politiet og staten har fått fullmakter til å operere i grensen av rettssikkerhetsgarantiene burde være et betent spørsmål etter at den norske Lund-rapporten ble avgitt Stortinget i 1996. Lund-kommisjonen dokumenterte nemlig omfattende ulovlig overvåking av norske borgere. Det er også urovekkende at det stort sett tas for gitt at dette vil redusere kriminalitestrusselen. Det blir sjeldent stilt spørsmålstegn ved både prinsipielle sider ved politikontroll, og om det i det hele tatt er samsvar mellom trusselbilder og metoder som tas i bruk. En nylig utgitt bok som tar opp disse aspektene ved nye politimetoder, er artikkelsamlingen Brottsbekämpning - mellan effektivitet och integritet: kriminologiska perspektiv på polismetoder och personlig integritet, redigert av den svenske kriminologen Janne Flyghed. Hovedfokus er å problematisere forholdet mellom en effektiv kriminalitetsbekjempelse og respekten for menneskelige fri- og rettigheter. Selv om det ikke er særlig debattert i det offentlige rommet, er konflikten mellom polisiær effektivitet og borgernes integritet av spesiell interesse i stater som definerer seg som rettstater og demokratier. Som et overgripende tema er det de prinsipielle sidene ved en generell kontroll og overvåking av alle for å forhindre at et fåtall begår lovbrudd, som diskuteres. Ekspansjonen i politiets inngrepshjemler, overvåking og militarisering av politiet settes i kontrast med de rettigheter som garanteres gjennom den rettsstatlige garantier.

"Brottsbekämpning" består av ni kapitler, hvor de tre første tar for seg begreper og prinsipielle spørsmål, mens de fem påfølgende fokuserer på ulike konkrete empiriske eksempler. Det avsluttende kapitlet sammenfatter både eksemplene og perspektiver for å si noe om dagens og framtidens kontrollsamfunn. Spørsmålet som avslutningsvis forsøkes å besvares er om det i det hele tatt er mulig å kontrollere kriminalitet på en måte som er en rettsstat og et demokrati verdig. De fleste av artiklene er skrevet ev Flyghed selv, de to andre bidragsytere er Antonia Ribbing og Bo Sandberg.

Ribbings artikkel om terroristlovgivningen illustrerer den overordnede problematikken. En kort gjennomgang av lovgivningens historie viser at den skjerpede innsatsen ikke kan forklares med faktisk forekomst av terrorisme. Selv ikke i et land som må leve med at deres statsminister ble henrettet, og at saken fortsatt er uoppklart, kan vise til faktiske terrorhandlinger (Det skal bli interessant å se hvordan "Kravallerna i Göteborg" blir tolket). Men påfallende nok kan såvel fravær av terror, som utbredt terror, brukes som begrunnelse for lovgivningens nødvendighet. Problemet med lovgivningen er at den ikke kan inneholde noen konkret bestemmelse av hvem som er terrorister. Samtidig er de handlinger som loven skal beskytte mot allerede forbudt innen den øvrige straffelov, også det å planlegge terrorhandlinger. Man står da igjen med en lov, hvis eneste selvstendige bidrag, er at den retter seg mot utenlandske statsborgere, og hjemler utstrakt bruk av tvangsmidler. Blir man mistenkt for å komme til å planlegge terrorhandlinger, blir en eventuell utvisningsbestemmelse foretatt av domstolen. Men siden saken er omgitt med problemer som "rikets sikkerhet", er mange av de omkringliggende forhold hemmelige. Anklagene blir det da umulig å forsvare seg mot. Hvordan er det da med rettsstatsprinsippene om at ingen skal dømmes uten å kunne forsvare seg? Et annet gjennomgangstema 
som også berøres i denne artikkelen er for hvilke grupper i samfunnet rettsstatsgarantiene faktisk gjelder. Er ikke Sverige, eller Norge, en rettstat for de som kommer tilreisende?

Man kan lure på om man skal le eller gråte når man leser den påfølgende artikkelen om den svenske innsatsstyrken mot terrorisme. Etter mye frem og tilbake, blir det vedtatt at man skal ha en slik i 1990. Når man så endelig klarer å finne fram til dugelige kandidater for jobben, er innsatsstyrken operativ med sine 56 mann i 1997. 56 av de beste politimenn i hele Sverige er klare til å bekjempe terrorisme. Problemet, og det er et problem for dem, er bare at det ikke finnes noe ordentlig terrorisme. De ble sittende virkeløse med alt sitt utstyr og kompetanse. Men om man velger å le av dette, er det med bekymring Flyghed konstaterer at den kompetanse, og ikke minst de fullmakter innsatsstyrken har, etter hvert trenger inn i det $\emptyset$ vrige politiarbeidet. En ting er den militarisering av politiet som opprettelsen av innsatsstyrken innebærer. Noe annet er at den militariserte politivirksomheten sprer seg til den daglige politivirksomheten. Det blir stadig oftere spurt etter innsatsstyrken i forbindelse med $\emptyset$ vrige politioperasjoner, selv om disse ikke har vært rettet mot terrorvirksomhet, for eksempel MC-gjenger. Flyghed trekker fram flere enkeltepisoder der det ordinære politi er blitt utsatt for kritikk, og at disse hendelsene brukes som brekkstang for å utvide innsatsgruppens arbeidsområde. Her henvises det til amerikanske og engelske forhold, hvor denne utviklingen har gått enda lenger.

Disse kapitlene utgjør sammen med en artikkel om endringer i politiarbeidet (fra reaktivt til proaktivt), en annen om rom- og telefonavlytting og en tredje som tar opp fri- og rettigheter ved $\varnothing$ konomisk kriminalitet og narkotika, den empiriske delen av boka. Disse danner figur for det generelle resonnementet, som fremføres av Flyghed. Flyghed mener det foregår en utvidelse av den polisiære kontroll på bekostning av den personlige integritet. Denne bæres fram av 1) dyrkelse av fiendebilder (som myndighetene har fremlagt uten empirisk belegg) 2) "normalisering av det eksepsjonelle", både når det gjelder fiendebilder og mottiltak.

Fiendebilder innebærer at man fratar de som tilhører en bestemt kategori (for eksempel narkomane) den verdighet som ligger i den universelle rettsikkerhetsgarantien. Dette demonstreres med all ønskelig tydelighet i Bo Sandbergs artikkel "Likhet för lagen? Om fri- och rettigheter vid ekonomisk brottslighet och narkotika". Spørsmålet om hvem rettsgarantiene gjelder for blir her nemlig enda skarpere stilt enn i artikkelen om terroristlovgivningen. Narkotika er et lovbrudd forbundet med langt større fiendepotensiale enn $\emptyset$ konomisk kriminalitet, og der blir da heller ikke integritetsapektet særlig vektlagt. I lovforslagene fremsatt under behandling av straffeskjerpelser for de omtalte lovbruddstypene, blir intergritetsaspektet praktisk talt aldri vurdert i forbindelse med narkotikalovbrudd. Og dette gjelder alle partier. Motsatt er det et gjennomgangstema i behandlingen av økonomisk kriminalitet, selv om det er en viss skjevhet mot de konservative partiene.

Flyghed antyder at det foregår en normalisering fiendebilder, en slags gjentagelsens monotoni, som overdøver reelle farevurderinger ved de enkelte grupperinger. Det foregår altså en moralsk fordømmelsesproduksjon som mangler empirisk grunnlag. Her lanserer han begrepet "normalisering av det eksepsjonelle". Men det foregår også en normalisering av det eksepsjonelle når det gjelder mottiltak. Som eksempelet med innsatsstyrken mot terrorisme viser, blir den eksepsjonelle bruken av militære midler i politiarbeidet gradvis normalisert. Tilsvarende gjelder for avlytting og bruk av tvangsmidler generelt. 
Normalisering av det eksepsjonelle fører til at de integritetsbevarende elementene i kriminalitetsbekjempelsens erstattes av effektivitetshensyn. Balansen mellom individ og stat forrykkes, og det er individet som er taperen. Ribbing gjengir en formulering fra den kjente jusprofessoren i Lund, Per Ole Träskman: 'Terrorismen kan inte lagstiftas bort. Däremot kan det som kallas rättstaten lett förintas genom ny lagstiftning" (side 114). Med bakgrunn i de to innledende artiklene i boken, om forholdet mellom individ og stat og om rettssikkerhet og integritet, kommer enkelheten i dette tydelig fram.

Flygheds kritikk av utviklingen er konsentrert om mulighetene for at folk som i dag nyter godt av rettssikkerhetsgarantiene, en dag vil oppleve å være ekskludert fra dem. Her er han lite konkret, men det er nærliggende å tenke seg politiske aktivister på venstresiden og miljøforkjempere. Som Flyghed viser i artikkelen om "buggning" ser vi at det allerede i dag ikke finnes noe effektivt vern mot avlytting av enkeltpersoner dersom politiet, av en eller annen grunn, skulle ønske å overvåke vedkommende. Lund-kommisjonen avdekket at dette er relevante problemstillinger også i Norge. En normalisering av de eksepsjonelle tvangsmidlene kan etter hvert strekke seg ut til snart å ramme det som i dag betraktes som legitim virksomhet. Men da må den være oppbacket av en moralsk fordømmelse av de gjeldende grupperinger, anses som en trussel og funderes i pressgruppers interesser.

Et sentralt moment i denne kritikken, er endringene i politiets arbeidsmåter. Det som skjer er at politiet i større og større grad institusjonaliserer en etterretningsmetode hvor handlinger erstattes av personer som mistenkelig objekt. Det er ikke det man har gjort som etterforskes, men personer med mistenkelige egenskaper, livstiler, atferder og kanskje synspunkter som granskes av etterretningsvirksomheten. Man kan mene hva man vil om forebyggende politiarbeid, men det heter seg i grunnloven at ingen kan dømmes uten etter lov, og straffes uten dom. Sånn sett er det lov å etterforske før en ulovlig handling er begått, eller uten at en slik noensinne blir begått. Men det rimer dårlig med de rettsstatlige prinsipper at dette i stigende grad preger politiets arbeidsmåte. På denne måten endres politiets praksis fra handlinger til mistenkelige personer, og defineringen av hvem som er mistenkelige er ikke underlagt demokratisk kontroll. Flyghed mener det er fire hovedfaktorer som har ført til denne endringen i politiarbeidet, nemlig internasjonalisering av politisamarbeid, nye trusselbilder som politiet skal bekjempe, krav om at politiet skal bli mer effektivt og teknologiutviklingen som blant annet har skapt muligheten for kombinasjoner av forskjellige typer av overvåkingsteknologier som bilde, lyd og tekst.

Slik ligger det innebygget en selvforsterkende mekanisme i den rettsstaten som er under utvikling. En rettsstat som ekskluderer stadig flere av sine medlemmer. Flyghed peker på fire aktører som spiller en rolle i denne prosessen; nemlig politikere, politiet, kontrollindustri og media. Dette gjør han uten å bli konspiratorisk. Det er nemlig ikke bevisste motivasjoner som ligger bak, men en rekke krefter, både interne og eksterne rasjonaliteter i de nevnte aktørenes virksomhet, som i vekselvirkning forsterker prosesser som til sammen peker i samme retning.

Flyghed og hans medarbeidere har utvilsomt skrevet en bok som er både relevant og viktig for både norsk og nordisk kriminalpolitikk. Vi vil likevel fremføre et par mindre kritiske merknader. Flygheds kritikk har tendenser til fellestrekk med den nye tabloidjournalistikken, en henvendelse til leseren om at dette kan hende "deg". Og selv om dette rommer en kjerne av sannhet, er det vår oppfatning at det ikke er et nødvendig grep for å 
fange leserens oppmerksomhet. Eksemplene og rammene de settes inn i er skremmende nok i seg selv. Et annet savn er at ingen artikler tar opp hva dette gapet forteller om vår samfunnsform. Hvorfor skjer denne endringen, og hvorfor blir det ikke kritisert i det offentlige rom? Hvorfor er trygghetsbehovet så viktig at man sluker nye tiltak uten å unders $\varnothing \mathrm{ke}$ om de kan avverge truslene som motiverer dem? Hva betyr det at vi heller vil være konsumenter enn borgere - og nettopp derfor gir fra oss frihet for å oppnå goder og fylle et trygghetsbehov? Innen kriminalpolitikkens område beveger vi oss nå mot snevrere grenser for hvem som defineres $\mathrm{i}$ inn-gruppen. Dette til tross for at vi til nå har sett en nærmest kontinuerlig prosess for større inkludering. I Norge skryter vi av å være forkjempere for de universelle menneskerettigheter, rettigheter som følger et menneske uansett rase, posisjon i arbeidslivet, kjønn, sivil status, kultur, seksuell legning, rulleblad og politisk oppfatning. Vi prøver til og med å eksportere menneskerettighetene til andre land. Og overfor andre land i Europa, som den tidligere øst-blokken, vil vi vise fram vår rettsstat som et forbilde. Men det å fortolke hva dette forteller om samfunnet, kan jo være tema for en annen bok eller artikkelsamling.

Ved å stille det prinsipielle spørsmål om effektivitet på den ene siden og integritet på den andre siden, er det nemlig ingen tvil om at det er skrevet viktig bok, som også er relevant for lesere i andre nordiske land enn Sverige. Sverige har jo enda ikke hatt noen Lund-kommisjon, men denne boken gir en pekepinn om at forholdene er ganske like i Norden. I boka finnes det et rikt tilfang av henvisninger til norsk forskning (selv om en kjedelig mangel ved boken er at litteraturlista ikke er komplett ut fra referanser som er brukt), og mange av temaene som tas opp har klare paralleller til i hvert fall det norske politiske landskapet. Bokas viktighet er likevel at den stiller seg kompromissløst som forsvarer av rettsstaten, overfor en utvikling som truer med å undergrave hele vår forfatning.

\section{Nicolay B. Johansen og Helene O. Gundhus Universitetet i Oslo}

Samuel Cavallin: Skuld. Andra upplagan. Iustus förlag, Uppsala 1999.

Samuel Cavallin har skrivit en mycket omfattande bok om skuld. Skuld är Cavallins doktorsavhandling. Jag kommenterar här i all korthet en andra upplaga av Skuld, men skillnaderna till den första upplagan torde vara rätt små (se Förord). Boken har hela 810 sidor.

Cavallin har indelat boken i fem stora kapitel. Först kommer dock en inledning (11-23). Det första kapitlet Om Tillräknande av straffansvar (24-146) ägnas huvudsakligen en granskning av brottsbegreppet i tysk, engelsk och nordisk doktrin. Därefter följer tre dogmatiska kapitel, av vilka två är mycket omfattande: Dolus (kap. 2, 147-356), Försök (kap. 3, 357-399) och Culpa (kap. 4, 400-602). I kapitel fem (603-767) finns det till slut en redogörelse över Cavallins granskning av 1013 tingsrättsavgöranden som gäller livsbrott och grova misshandelsbrott. Av dessa genomgås 86 representativa fall mera ingående. I boken ingår också ett sammandrag på engelska (768-784) samt källförteckning och sakregister.

Skuld kan ha många betydelser. På vilket sätt försök hör till bilden kan man fråga sig. I framställningen har försök dock en underordnad betydelse i förhållande till dolus och culpa. Frågan om t.ex. uppsåt vid försök betyder samma sak som vid fullbordade brott är 
givetvis viktig. Cavallin är mest intresserad av uppsåtets nedre gräns. Detsamma gäller mina kommentarer.

Cavallins metod kan sägas vara den vanliga i och med att den baserar sig på doktrin, praxis, förarbeten och lag. Cavallin tillmäter dock underrättspraxis en stor vikt. Detta har samband med att rättskällornas betydelse enligt Cavallin också borde kunna bedömas självständigt. Det är något snett i det att man är hänvisad till doktrinens värdering av praxis (prejudikat); genom att granska underrättspraxis kan man se vad praxis "säger om sig själv" (19-21, 194). Jag finner det i och för sig bra att någon inte bara arbetar med prejudikat, utan redan till följd av underrättsavgörandenas stora kvantitativa betydelse också ägnar det som händer på underrättsnivån uppmärksamhet. En sådan undersökning kan konstrueras på olika sätt. Cavallin är främst ute efter att granska om avgörandena (motiveringen till dem) bygger på de vanliga teorierna eller om det är något annat som synes styra dem.

Den historiska utvecklingen och hanteringen av skuldbegreppet har varit viktiga för Cavallin. I en gammal germansk inkvisitorisk process började man med en generalinkvisition, där man fastställde att ett brott, inklusive uppsåt, hade begåtts. Först i specialinkvisitionen koncentrerades på vem som var gärningsperson. Uppsåtet hörde så att säga till gärningen, inte gärningspersonen. Men upplysningens syn på människan och mänskliga handlingar blev i mekanikens, den nya naturvetenskapens och Descartes' anda präglad av en ohjälplig dualism $(150,242-244,563-564)$. Och i och med genombrottet av det klassiska brottsbegreppet mot slutet av 1800-talet, gjordes skulden (onödigt) till ett märkligt och komplext fenomen (64, 191-192, 352-353). Det klassiska brottsbegreppet indelas i en objektiv och en subjektiv sida. Uppsåt är då i princip något som prövas separat efter att de objektiva rekvisiten har granskats. Uppsåtet görs till ett inre faktum. Detta är det grundläggande felet, dualismen, som plågar brottsbegreppet och skulden. Problemet är att bara gärningspersonen, om ens hon, kan se in i sitt huvud. Ett dylikt inre faktum kan inte bevisas med sådan säkerhet som måste krävas i brottmål (173-174). Ett annat dualistiskt drag, rotat i samma tid och paradigm som dagens straffrättsdogmatik, har också bidragit till skuldens nutida komplexitet: isärhållandet av materiell rätt och processrätt $(46,151)$. Cavallins arbete kan ses som en kamp mot dualismen och dess (dåliga) följder för skuldbegreppet.

Inom det sedvanliga paradigmet torde man mycket förenklat, utifrån doktrinära mallar, kunna beskriva uppsåtets nedre gräns i Sverige enligt följande. Det danskt-norska sannolikhetsuppsåtet har av HD avvisats ett par gånger (NJA 1959 s. 63 och 1980 s. 514). Den hypotetiska viljeteorin har haft en betydande ställning i praxis. Av Cavallins arbete kommer dock fram att den hypotetiska viljeteorin har spelat den största rollen vid försök och vid förkastande av åtal $(302,351-352,749-751)$. Under nyare tid har också något slags likgiltighetsuppsåt använts (NJA 1985 s. 757 m.m.). Straffansvarsutredningen (SOU 1996:185) vill införa en uppsåtsdefinition, enligt vilken en gärning begås uppsåtligen "om den är avsiktlig eller om den motsvarar vad gärningsmannen har insett, uppfattat eller antagit om den".

Uppsåt som ett inre faktum kan enligt Cavallin alltså inte bevisas. En ärlig väg ur detta problem är inte det att man säger sig bevisa inre fakta genom yttre omständigheter (17). En bättre väg är att avskaffa den dualistiska grundsynen och frigöra sig från inre fakta såsom bevistema $(144,204,353)$. Cavallins lösning blir då dolus ex re-gärningsuppsåt (GU). En väsentlig inspirationskälla har Cavallin funnit i R.A. Duffs arbeten. Grundidén 
är att uppsåtet manifesterar sig i gärningen, man behöver inte gå in i gärningspersonens huvud. Detta gäller också försöksgärningar (373). Allt uppsåt är i princip gärningsuppsåt, men man kan skilja mellan två slags uppsåt. För det första finns det uppenbart uppsåt: "Uppsåt kan klassificeras som uppenbart och bestämt uppsåt genom att gärningen i sinnevärlden direkt avslöjar sitt syfte eller sin mening" (se 259). Utöver detta finns det egentliga gärningsuppsåtet, icke-uppenbart men ändå säkert gränssättande uppsåt. Här ligger enligt Cavallin "säkert konstaterbar mening genom att gärningen visar sig vara särskilt typisk eller meningsfull i en viss riktning" (se 260). En bra generell beskrivning av när detta är fallet har jag dock inte lyckats finna i boken. Klart är emellertid att GU:s sedvanliga ingredienser är kraften i våldet, vapnets typ, den vitala del som våldet har riktats mot och sättet i övrigt (se t.ex. 310, 346, 670, 754). Intrycket är att den objektiva sannolikheten för följden skulle vara ett mycket betydande kriterium. Men det är inte bara graden av risk som är väsentlig, utan även t.ex. gärningsmedlens typiskhet (se 317 , 595-596, 760-761). Ett annat svar på frågan är att säkert uppsåt är för handen utgående från vissa specifika kriterier utvecklade i praxis (355).

Enligt Cavallin spelar GU en betydande roll i fråga om såväl prejudikat som underrättspraxis. I prejudikaturen finner Cavallin GU representerat bl.a. i de i doktrinen mycket omdebatterade NJA 1977 s. 630, 1985 s. 757 och 1996 s. 509 (Klippanmålet). Samtliga gäller uppsåtets utsträckning vid knivhuggning. I NJA 1977 s. 630 anförde HD om uppsåtet: "Vad härefter angår frågan huruvida TT handlat med uppsåt att döda offret är i målet utrett, att knivhugget träffat i trakten av hjärtat och utdelats med den kraft att kniven trängt in 7 à 8 centimeter in i offrets kropp. Vid avsiktligt knivhugg av detta slag måste en dödlig utgång ha för gärningsmannen framstått som praktiskt taget oundviklig. Offrets död har därför omfattats av TT:s uppsåt". I fallet NJA 1985 s. 757 (med en 25 cm lång fiskkniv tre gånger i nacken och en gång i vänster sida av bröstet) fällde HD för dråp: "Skadornas art och det sätt på vilket de tillfogats offret visar att TT vid huggen i vart fall varit helt likgiltig för om offret skulle dö eller ej. TT kan därför inte undgå ansvar för uppsåtligt dödande". I Klippanmålet hade offret huggits med en kniv vars blad var 10,8 cm långt, en gång $3,5 \mathrm{~cm}$ till vänster om bröstets medellinje och ca $6 \mathrm{~cm}$ ovanför bröstbenets nedre kant. HD fällde gärningspersonen för mord, och uppsåtsmotiveringen liknade 1985 års fall. Motiveringen till 1977 års fall kallar Cavallin "rent” gärningsuppsåt (305), de två senare fallen representerar likgiltighet som gärningsuppsåt [där likgiltighet har rollen av ett mellanled mellan omständigheter som grundar GU och omdömet uppsåtlig (se 328-329)]. Dagsläget verkar enligt Cavallin peka mot en kombination av gärningsuppsåt och likgiltighetsuppsåt $(305,329)$.

GU:s väsentliga roll kommer också till synes i underrättspraxis (746-755). I 284 fall av uppsåtligt dödande formulerades uppsåtet enligt följande: 1) uppenbart, bestämt, direkt eller indirekt uppsåt: 64 fall, 2) dolus eventualis: 56, 3) GU: 94, 4) sannolikhetsuppsåt: 7,5 ) culpa: 25,6 ) medvetenhet: 3,7 ) inget resonemang i uppsåtsfrågan: 35 (se närmare 616-618 och 636; likgiltighetsfallen är med i kategorierna dolus eventualis och GU). Granskningen för fram intressanta likheter och olikheter beroende på om det t.ex. är fråga om mord eller dråp, självständigt eller osjälvständigt brott och beroende på de åtalades olika inställningar till åtalet. Man skulle kanske också ha kunnat granska materialet ur den synvinkeln, vilka som är de faktiska sakkriterierna för uppsåt [är t.ex. ett kraftigt knivhugg i buken, oberoende av använda formuleringar, tillräckligt för (försök till) dråp? (se också NJA 1980 s. 514, där gärningsmannen dömdes för grov misshandel)]. 
Också en sådan frågeställning är väl naturlig särskilt när man företräder en dolus ex resyn på uppsåtet. Cavallin gör rätt $\mathrm{i}$ att betona att hans resultat gäller våldsbrott (408-409), vilket gör att man inte utan vidare kan hävda att uppsåt ser likadant ut också vid andra brottstyper.

Cavallin har inget större intresse för att delta i den sedvanliga kampen om den "riktiga" gränsdragningen mellan dolus och culpa. Dolus ex re-gärningsuppsåt är hans ickedualistiska lösning på problematiken. Sedvanliga uppsåtsteorier finner han mer eller mindre som parafraseringar, som inte är ägnade att leda till klarhet (257-258, 355-356). Också Straffansvarsutredningens insiktsuppsåt finner han vara en dylik kvasilösning $(273,356,757)$.

Om culpa må nämnas att Cavallin kritiserar lärorna om culpans två sidor åtminstone till den del de återspeglar en dualistisk utgångspunkt (t.ex. 404). Också GU är i viss mening oaktsamhet; avvikelserna från vad som är godtagbart beteende är emellertid så pass stora vid uppsåt att gärningen manifesterar sig i sinnevärlden som uppsåtlig (262, 415, 597).

Att kommentera Samuel Cavallins Skuld finner jag inte enkelt. Utifrån "härskande läror" framstår arbetet väl inte alldeles invändningsfritt. Han synes med sitt i gärningen manifesterande uppsåt företräda någon sorts objektiv dolusmodell. Men dylik kritik förevisas ur den traditionella synvinkeln. Och den vill Cavallin kritisera. Kanske finns det inte "a view from nowhere". Dessutom kan Cavallins utgångspunkt vara riktig: uppsåt som inre faktum är egentligen ett omöjligt bevistema. Men lyckas Cavallins modell undvika det subjektiva?

Arbetet väckte några frågor hos mig. Vad är icke-dualism? Är den någon sorts omfattande fundamentalontologi eller bara något som rör t.ex. det straffrättsliga brottsbegreppet? Vi får dock veta att av Cavallins icke-dualism inte följer att inre fakta inte skulle existera eller att det skulle vara omöjligt att uttala sig om inre fakta. Ett inre faktum skulle bara inte kunna vara föremål för bevisning (16-17, 242). Även om det i fråga om uppsåt blev rätt klart vilka omständigheter som är väsentliga för GU (t.ex. våldets art och riktning samt eventuellt vapen m.m.), blev dess egentliga definition för mig lite oklar; skulle t.ex. lagstiftaren kunna definiera uppsåt enligt GU? Även om tillräknelighet för tillfället inte är en brottsförutsättning enligt svensk straffrätt, och inte heller behandlas ingående i boken, torde den icke-dualistiska skuldsynen ha en inverkan också på den.

Jag finner det bra att Cavallin betonar uppsåtsbevisningen samt att han gör bruk av rättshistoria och rättshistoriska mönster i sitt omfattande arbete. Också bl.a. det att han relaterar dolus- och culpadiskussionen till anglosaxisk begreppsbildning och praxis finner jag mycket värdefullt.

\section{Jussi Matikkala}

Helsingfors universitet

Jürgen Welp: Überwachung und Kontrolle. Telekommunikationsdaten als Gegenstand strafprozessualer Ermittlungen. Duncker \& Humblot, Berlin 2000. ISBN 3-428-10255X. 156 pp. 98 DM.

So fühlt man Absicht, er med Goethes Tasso anmelderens første reaktion på en bog, som først så dagens lys som responsum for det største tyske telefonselskab Deutsche Telekom $A G$ og munder ud i en argumentation for at vederlægge telefonselskabernes arbejde ved 
den tvungne udlevering af elektroniske oplysninger om telefonsamtaler, særlig hvilke numre der har været i forbindelse med et bestemt andet nummer. Men ved endt læsning er læseren alligevel ikke verstimmt, idet forf., som åbent bekendtgør værkets genesis i forordet, ikke har solgt sin sjæl, men uddybet synspunkter forfægtet siden 1974, hvor han udgav afhandlingen Die strafprozessuale Überwachung des Post- und Fernmeldeverkehrs.

Emnet for denne tætte lille bog er den for tysk ret særegne, i 1927 indførte og aldrig ophævede adgang for anklagemyndigheden til at afkræve telefonvæsenet oplysning om opkaldte numre og samtalers varighed til brug for efterforskningen, oplysninger allerede foreliggende til brug for den løbende udskrivning af regninger. Indgrebet havde begrænset praktisk betydning i telefonens første år, hvor telefonbetjeningen var manuel. I kommunikationsteknikkens næste, elektromekaniske fase, hvor gebyrer beregnedes straks og alle oplysninger om det opkaldte nummer udslettedes ved samtalens afslutning, med forf.s ord der datenschutzrechtliche Idealfall (p. 16), forsvandt det, men genoplevedes med den nu anvendte digitale teknik. Det har fået voldsom betydning ved udviklingen af Zielwahl-Suche siden 1997 (p. 20 f.), en forfinet teknik til at udfinde ikke blot, hvilke apparater den relevante abonnent $\mathrm{A}$ har ringet til, men også fra hvilke apparater der er ringet til $\mathrm{A}$, oplysninger som jo ikke fremgår af A's egne regninger, da betaling herfor ikke afkræves A, men alle opkalderne hver for sig.

Også en forhærdet pragmatisk forfægter af den materielle sandheds princip - som anmelderen - kan se tysk rets paradoks. I visse måder er individets retsbeskyttelse meget stærk, hvilket kan have vidtrækkende og stærkt tyngende konsekvenser, f.eks. ved reglen om efterfølgende oplysning om indgreb i meddelelseshemmeligheden. Her kræver dansk Rpl. § 788 kun underretning til indehaveren af "den pågældende" (f.eks. en aflyttet) telefon, StPO $\S 101$ derimod underretning til die Beteiligten, dvs. indehavere af alle apparater, som har været forbundet med det aflyttede apparat, endog indehavere af apparater, hvor efterforskning under Zielwahl-Suche har bevist, at de ikke har været forbundet med apparatet (p. 64 f.), idet den grundlovsbeskyttede telefonhemmelighed omfatter ikke blot "wie", en samtales indhold, men også "ob", om samtalen overhovedet har fundet sted (p. 26). Forf. kræver sågar efterforskning efter ukendte "Beteiligte", men står dog her alene. Grundlovens retsstatsprincip giver derhos mulighed for ekstra efterprøvelse, når den almindelige lov selv legitimerer et indgreb - bogens gennemgang af grundlovsprøvelsen er næsten lige så fyldig som af 1927-loven, 35 pp. mod 48 pp. De gængse regler om aflytning m.v. er i tysk ret meget lig de danske særlig ved at være begrænset til nærmere opregnede grove forbrydelser, det såkaldte "Katalog", også selvom de stadige udvidelser af adgangen til aflytning gør den relevante bestemmelse, StPO $\S 100$ a, til den hyppigst ændrede $\S$ trods sin unge alder, 15 gange efter indførelsen i 1968.

Heroverfor står 1927-loven, som kan anvendes ved samtlige overtrædelser (p. 37 f.) og uden vilkår om mistankens styrke eller indgrebets nødvendighed. Netop ved omtalen af kravet om, at andre efterforskningsmidler er uforholdsmæssigt tyngende eller rent ud umulige, udviser forf. velgørende realitetssans eller resignation, idet retterne næsten aldrig er i stand til at bedømme dette; subsidiaritetsklausuler er kun et venligt slør over det forhold, at tekniske indgreb altid er tilladelige, når de giver udbytte (p. 86 f.).

Den væsentligste grænse er lovens brug af præteritum i verberne, waren m.v., hvilket gængs lære, også forf., fortolker, således at der kun kan kræves oplysning om afsluttede kommunikationer. Naturligvis har anklagemyndigheden forlængst gennembrudt 
begrænsningen ved at forny begæringen, lovligt men upraktisk, og nogle retter har af praktikabilitetsgrunde i de seneste år givet adgang til at kræve oplysning om uafsluttede forløb; “Förmelei” har en Landgericht kaldt indskrænkningen til det fortidige. Også en så væsentlig forfatter som Wolfgang Bär, hvis værk om de strafferetlige tvangsindgreb jeg har omtalt i NTfK 1993, p. 108 ff., vil nu modsat sin tidligere opfattelse anerkende denne udvidelse, som forf. hudfletter (p. 52 ff.). Af sprogligt-historiske grunde er den gængse fortolkning muligt den rette, men den er unægtelig upraktisk.

Særlig kritiserer forf. den teknisk meget indgribende Zielwahl-Suche, som han finder grundlovsstridig, idet oplysninger om opkald fra andre telefoner ikke har betydning for gebyrberegningen for den opkaldte telefon, hvorfor selskaberne ved at fremskaffe og videregive disse oplysninger selv bryder den grundlovssikrede telefonhemmelighed ( $\mathrm{p}$. 102). Med den usikkerhed, som sømmer sig den ikke-tyske jurist, vil jeg betvivle forf.s opfattelse, særlig fordi den ønskede viden om, at telefon B, C etc. etc. (ikke) har været forbundet med telefon $\mathrm{A}$ i en bestemt afsluttet periode, allerede eksisterer som historiske oplysninger, om ikke ved de A vedrørende "akter", så ved B, C etc. etc., og ikke skal fremdrages de novo som ved samtidig aflytning. Medens jeg er enig med forf. (p. $82 \mathrm{f}$.) om, at der er et dilemma mellem de strenge betingelser for indgreb efter StPO og de meget løse forudsætninger for indgreb efter telefonloven af 1927, finder jeg det mere end betænkeligt at karakterisere denne diskrepans som grundlovsstridig.

Vederlagsspørgsmålet, den direkte anledning til bogen, fors $\emptyset$ ger forf. at løse ved analogi fra en ændring i 1992 af lov om vidnegodtgørelse m.v., som indførte betaling for brug af privatejede databehandlingsanlæg under såkaldt Rasterfahndung, sammenkøring af flere registre under efterforskning af særlig opregnede grove forbrydelser, gennemført ved samtidig ændring af StPO. Efter min opfattelse er analogien uholdbar. Nok er det rigtigt, at da Zielwahl-Suche kun har været kendt siden 1997, kunne lovgiver ikke i 1992 forudse nødvendigheden af at indpasse denne i vidnegodtgørelsesloven (p. 129 f.), men siden vederlag aldrig har været ydet for oplysninger efter 1927-loven, må der mere til end en teknisk forbedring af fremgangsmåden og den deraf forøgede brug af indgrebet for at etablere et hul i loven, en Regelungslücke, som kan legitimere en analogi fra en formentlig sjældent anvendt regel til et i praksis uhyre hyppigt indgreb. Man kan vende forf.s argument mod ham selv og sige, at når lovgiver siden 1997 fortsat har undladt at skabe hjemmel til betaling, må dette være tilsigtet. Muligt kan det retspolitisk tale for vederlag, at telefonvæsenet ikke længere er offentligt, men nu både privatiseret ved omdannelsen af Deutsche Post til Deutsche Telekom AG og liberaliseret ved afskaffelse af det hidtidige monopol, hvorfor forf.s kritik af den i retspraksis bestående opfattelse om et særligt pligtforhold for netop Deutsche Telekom AG over for staten langtfra er ubegrundet (p. 129). I dansk praksis betales i øvrigt 6.000 kr. pr. måned pr. apparat - både faste og mobiltelefoner - for historiske oplysninger, uanset om de er mange eller få eller slet ingen, en noget (for?) høj betaling. Sammenfattende synes det mig, som om forf. har ladet sine retspolitiske ønsker farve fortolkningen af gældende ret.

Som det ses, er jeg langtfra enig med forf., men han rejser og behandler rigtig spændende spørgsmål.

\section{Peter Garde}

Hillerød kriminalret 
Thomas Haaland: Vold - konflikt og gjengdannelse. En unders $\phi$ kelse blant ungdom i fire byer. Prosjektrapport 2000:14. Norsk institutt for by- og regionforskning (NIBR), Oslo, 2000. (84 sider + bilag).

Nærværende unders $\emptyset$ gelse udg $\varnothing \mathrm{r}$ en del af et større forskningsprojekt om bl.a. problemadfærd, rusmiddelbrug, vold og bandetilhørsforhold i et ungdomsmiljø. Rapporten ligger tematisk i forlængelse af "Vold og gjengatfærd - et pilotstudie av et ungdomsmiljø" (Lien, I-L. og Haaland, T., 1998) anmeldt i NTfK nr. 4/2000.

Denne delunders $\emptyset$ gelse, der siden hen skal suppleres med en kvalitativ unders $\emptyset$ gelse, er en spørgeskemaundersøgelse gennemført blandt grundkursuselever i videregående skoler i Drammen, Kristiansand, Stavanger og Oslo. I alt 4702 unge mellem 15 og 17 år har besvaret spørgeskemaerne. (Svarprocenten i de udvalgte klasser var $88 \%$ ).

Spørgeskemaet indeholder detaljerede og mange spørgsmål om de unges erfaringer med vold og trusler (som vidner og ofre), egne erfaringer med voldsudøvelse, bevæbning samt viden om/erfaringer med ungdomsbander. Disse spørgsmål udgør mere end 50 spørgsmål ud af skemaets godt 90 spørgsmål. De resterende spørgsmål omhandler bl.a. de unges herkomst, familieforhold, tryghed/angst, jævnaldrendenetværk, færden i fritiden, økonomi og mobiltelefonbrug, forældres kendskab til de unges færden, rusmiddelforbrug og skoleaktivitet.

Undersøgelsens kan dermed ganske grundigt belyse det, som titlen også antyder: De unges volds- og konfliktadfærd, medens den ikke går i dybden med de unges liv i øvrigt. Dette begrænser mulighederne for at begribe/tolke i en bredere ungdomskontekst.

Til sammenligning kan Balvigs selvrapporteringsundersøgelse studeres (RisikoUngdom, Det Kriminalpræventive Råd, 1999). Denne undersøgelse er beslægtet med Haalands, men indeholder langt flere og mere detaljerede spørgsmål om de unges liv og holdninger mere generelt, hvilket giver et noget sikrere grundlag for at begribe sammenhænge. Det er derfor godt, at nærværende unders $\emptyset$ gelse af Haaland skal suppleres med en kvalitativ undersøgelse.

Nogle af undersøgelsens resultater: Godt hver tredje informant oplyser, at de har været udsat for vold eller trusler inden for det seneste år, og de fleste af disse har været udsat mere end én gang. Andelen af piger, der har været berørt af vold, er i flg. Haaland steget de seneste 10 år, men pigerne rapporterer dog fortsat færre og mindre alvorlige hændelser end drengene.

Unge med anden etnisk baggrund end norsk er noget sjældnere ofre, men de, der har været ofre, har oplevet dette tiere og mere alvorligt end unge af norsk oprindelse.

Der ses en ikke overraskende stærk sammenhæng mellem voldserfaringer, brug af rusmidler og selvorganiseret fritidsliv især i det offentlige rum. Haaland konkluderer, at unge, hvor denne sammenhæng er udtalt, oftere er i konflikt og udviser konfliktadfærd bl.a. i form af mere eller mindre offensive forholdemåder til fremtidige potentielle episoder. Denne sammenhæng er dog ikke så entydig for så vidt angår unge med fremmed etnisk baggrund. De er oftere udsat for vold uden at have erfaringer med rusmidler.

På trods af forfatterens egen pointering af, at spørgeskemametoden og de relativt begrænsede spørgsmål desangående ikke er velegnede til at belyse spørgsmål om bandetilhørsforhold, konkluderes det, at 5\% af de unge er med i en bande. Bande er i spørgeskemaet defineret som "en relativt fast gruppe ungdommer som av og til driver med vold og kriminalitet” (p. 68 og 102). Og på trods af at 729 af de 4702 informanter slet ikke har besvaret dette spørgsmål, konkluderes der videre om dette udsnits rusmiddels- og voldserfaringer, konfliktadfærd og -beredskab. 
Unders $\varnothing$ gelsens resultater forekommer ikke umiddelbart overraskende i $\varnothing$ vrigt, jfr. f.eks. den citerede undersøgelse af Balvig. Det er især i forhold til fortolkningerne af data og de ganske vidtgående forklaringer, at der kan knyttes kritik. Disse virker til tider lidt langt fra en mere bred forståelse af nutidig ungdom og ungdomsliv, og som om det kriminalistiske perspektiv har taget overhånd, hvorved helt almindelig ungdommelig adfærd gøres odiøs, f.eks. det faktum, at unge i aldersgruppen 15-17 år typisk færdes og agerer sammen med andre unge, at de ofte er på egen hånd og livligt kommunikerer med andre unge. Jeg skal give nogle eksempler på dette "kriminalistiske" perspektiv:

"...det synes klart at jenter i løbet af tiăret er blitt "mer like" guttene når det gjelder udsatthet for vold..." (p. 26). Jeg savner nogle få bemærkninger om at dette ikke er så sært. Piger og drenge er mere ens på en række måder. Piger færdes stadigt mere der hvor drenge færdes og gør de samme ting bl.a. i det offentlige rum. Måske kan den gradvise nivellering i forhold til pigers udsathed for vold og trusler netop skyldes at kønsforskelle langsomt jævnes - på godt og ondt.

Det siges videre (p. 39): "I og med at yngre ungdom ikke har lovlig tilgang til noen form for rusmidler (herunder alkohol, IK) er det grunn il å tro at rusbruk og voldserfaring er enda tettere forbundet enn i den voksne befolkning. Bruk af rusmidler blant ung ungdom må holdes skjult for voksne". Dette bruges til at argumentere for en tæt sammenhæn mellem rusmiddelerfaringer, voldserfaringer og selvorganiseret fritid uden voksenovervågning. Men kan man bare slutte således? Der spørges f.eks. ikke hvor alkohol indtages, om forældrene er vidne til indtagelsen og/eller accepterer dette. Danske undersøgelser vedr. unges alkoholvaner viser f.eks. at forældre er ganske liberale i forhold til deres børn og unges alkoholindtagelse. Af en dansk undersøgelse (Sabroe, K.E.: Skolealder og alkohol, 1997.) fremgår det f.eks, at 79\% af børn fra 4.klasse (ca. 10 år gamle) siger, at de har drukket alkohol sammen med deres forældre, og $16 \%$ siger, at de har været fulde sammen med deres forældre. Måske norske forældre og andre voksne er vældig anderledes end danske, men det vides ikke fra denne undersøgelse.

Og videre hævdes det, at "Barn og ungdom har klare forestillinger om grad av trygghet og utrygghet. [...] Den private sfære er trygg." (p. 42) Det kan hænde, at det ser sådan ud for de fleste. Men for nogle børn og unge, måske netop nogle af dem der opholder sig mest i det offentlige rum, forholder det sig faktisk omvendt. Ophold i hjemmet er farligt og utrygt f.eks. på grund af vold, skænderier, druk og måske krænkelser. Det offentlige rum er muligvis også utrygt, men alligevel tryggere. At være "ude" og sammen med jævnaldrende kan være det bedste alternativ af to dårlige. Undersøgelsen afdækker ikke de unges begrundelser for at opholde sig uden for hjemmet eller i en mere voksenorganiseret kontekst.

Og endelig lidt om "mobilen" $3 / 4$ af de unge der deltog i undersøgelsen har mobil. De der scorer højst på kriteriet selvorganiseret fritid taler meget mere i mobilen end de der scorer lavest, viser undersøgelsen. Det kan der jo være mange forklaringer på, men i rapporten gøres mobilaktiviteten nærmest til en kriminogen faktor: "...en melding via mobiltelefon (har) en ytterst individualisert og privat karakter. Meldingene kan nå fram til mottakeren uten at andre, familie, lærere eller $\emptyset$ vrige omgivelser, trenger å bli oppmerksom på det” (p. 48). Det fremgår ikke hvad de unge taler om, hvorledes mobilen anvendes osv. Derimod henvises til det tidligere pilotstudie vedr. en lille gruppe voldelige unge, der anvendte mobilen som "et sentralt redskap for kommunikasjon gjengmedlemmerne imellom" (p. 49). En simpel kvantificering af aktivitet på mobilen siger ikke 
noget andet end at de unge taler mere eller mindre, men brugen kommer i denne kontekst til at indebære helt særlige tolkninger og antydninger af noget problematisk i sig.

Til slut. Jeg finder det mærkeligt, at forskeren på første side af spørgeskemaet til de unge skriver: "Mye tyder på at bruk av vold, og trusler om vold er blitt en mer vanlig måte "å løse" konflikter på de siste årene. Særlig kan det se ut som om dette er blitt mer vanlig blant ungdom" (p. 85). Er det ikke at guide informanterne lige lovligt godt på vej?

\section{Ida Koch}

Frederiksberg Ungdomsrådgivning

Antologi. 8 reflektioner om kriminalpolitik. Brå-rapport 1999:9. Brottsförebyggande rådet, Stockholm 1999. 174 sider.

De tar opp mange ulike tema, de åtte som har bidratt med sine refleksjoner om kriminalpolitikk i denne antologien. Her er to tilnærmingsmåter: å gå inn i den kriminalpolitiske diskusjonen og delta med forslag, og å gjøre kriminalpolitikk til tema og se hvordan den har endret seg og hva som har hatt betydning for endringene. I flere artikler er begge tilnærmingsmåter brukt. I valg av konkrete eksempler handler de om ulike tema, men samtidig er det noen underliggende problemstillinger som dukker opp i flere av artiklene.

Antologien er utgitt av BR $\AA$ på initiativ av BRÅs vitenskapelige nemnd. To av bidragsyterne er kvinner, det er også innledningens forfatter, generaldirektøren for BRÅ. Og så deltar seks menn. Videre er to av bidragsyterne danske, fem skriver fra Sverige og en fra Finland, alt samordnet til svensk språk.

Dette startet som en bokanmeldelse, men ganske snart viste det seg umulig å skulle si noe samlet om de åtte bidragene, karakterisere eller vurdere dem. Det var mye mer fristende å ta utgangspunkt i temaene og bli med i diskusjonene - noe som forhåpentligvis er i denne antologiens ånd. Som man vil se, er det mye å tenke videre på, selvsagt også etter det som står her.

1) Flemming Balvig (FB) er førstemann ut og skriver om Folket, juristerna \& straffrätten. Hur attityder skapas genom avstånd - närhet. Avstand og nærhet er gamle kjenninger i kriminologien og FB viser nærhetens betydning i ulike typer sammenhenger. Hele tiden er det slik at nærhet - det vil si sosial nærhet, slik at Den Andre blir en person for oss - gjør det vanskeligere å være streng og dømmende i vår oppfatning eller valg av tiltak. Eksemplene peker frem mot et kriminalpolitisk punkt: bygg ned rammene rundt rettsapparatet, la den anklagete fremstå, ikke som et juridisk tilfelle eller allmenpreventivt eksempel, men som en person med sin historie og betraktninger. La folk bli forpliktet i forhold til rettergang og straff. En måte å få det til på, er å ta i bruk nærpoliti, konfliktråd og samfunnstjeneste, eventuelt at den dømte soner straffen i hjemmet, med fengsel som siste utvei. FB vil klippe konfliktene ut av rettsapparatet, som abstraherer hendelser og handlinger til juridiske betegnelser og gjør dem gangbare i en juridisk diskusjon, og som beskytter rettsapparatet mot å se noe særlig av personen som er tiltalt. Og så vil han lime konfliktene inn igjen i den sammenhengen de hendte $\mathrm{i}, \mathrm{og}$ dermed åpne for mangfoldighet i oppfatning og mulige tiltak, han vil gjøre konfliktene sivile igjen.

Abolisjonistene vil bygge ned og fjerne fengslene. Utopisk, sier mange. Kanskje de vil si det om FBs forslag også. Likevel er det noe mer overbevisende i dette fordi det ikke 
har ett enkelt mål, men tar sikte på å skape endringer i sosiale sammenhenger som vil kunne gripe inn i hverandre: Hvis folk deltar i konfliktrådsmeklingen med diskusjon og forslag, er det også sannsynlig at de vil være med på å finne konkrete løsninger, hjelpe og holde øye med personen underveis. Kort sagt, den sosiale kontrollen vil integreres i det lokale miljøet.

Hva med de spørsmålene som ofte dukket opp på 1970-tallet når slike forslag ble lagt frem: blir nærpolitiet kontrollert uformelt av omgivelsene, eller vil politiet utøve formell kontroll uformelt som igjen vil føre til et gjennomkontrollert lokalsamfunn? Hvem skal kontrollere kontrollørene? Opinionsundersøkelser FB refererer til tyder på at kontrollører som blir kjent med gjerningspersonen, blir forsiktige med å bruke straff. Det samme gjør vel også erfaringer fra konfliktrådsmekling. Men hva med iverksettingen av dommen, vil den bli for streng? Er den vesentlige forutsetningen tilstede, at folk bor i områder over lang tid, blir kjent og bryr seg om hverandre? I så fall var de kanskje helt forgjeves, bekymringene om at politiet, den formelle kontrollen, ville bli dominerende om den ble sluppet løs i nabolag. Eller kanskje tiden er en annen slik at vi ser det annerledes nå? Slike spørsmål dukker opp i forlengelsen av denne artikkelen. Samtidig blir leseren klar over at det ikke fins noe absolutt punkt for garanti mot overdreven bruk av kontroll, verken i formelle eller uformelle sammenhenger.

2) Lars Lidberg (LL) ivrer heller ikke for å bruke mer rettsapparat i artikkelen Rättspsykiatri \& farlighetsbedømningar. Med erfarenheten som instrument. Men fremfor å øke det sivile innslaget vil han ta i bruk et annet språk og system overfor siktete som er antatt å være alvorlig psykisk forstyrrete og/eller farlige. Hvilken posisjon har rettspsykiatrien i slike tilfeller? Hvilke faktorer har betydning for dens avgjørelser? Dette er noen av spørsmålene LL tar opp.

Bruken av rättspsykiatriske undersökningar (rpu) og psykiatrisk (sluten) vård i Sverige er i stadig mindre bruk og slik vil det fortsette, antar LL. Men én gruppe holder tallene oppe; innvandrere. Kanskje fordi de oftere er siktet for misbruk av narkotika, eller mer sannsynlig, på grunn av språkbarrierer i forhold til psykiatrisk helsepersonell. Dette er ett av LLs eksempler på at faktorer utenfor psykiatrien ser ut til å ha vesentlig betydning for dens avgjørelser.

Hva bestemmer innesperringstid i tvungen psykiatrisk behandling? Det skulle være pasientens tilstand. Men en sammenlikning av innsperringstid i ulike land mellom personer dømt til behandling og dem som settes i fengsel, viser at det er et påfallende samsvar mellom disse to typene innesperringstid. Dette kan bryte med Hawaiideklarasjonen som sier at når det ikke lenger er behov for tvang, skal den opphøre. Men sterke krefter trekker i retning av slike samsvar. I Sverige er det formalisert nå ved at andre enn psykiatere skal være med å bestemme innesperringstid for personer dømt til behandling.

Kan man finne frem til hvem som er 'allvarligt psykiskt störd' og hvem som ikke er? LL gir flere svenske eksempler på uenighet, som blant annet kan henge sammen med en lovendring i 1992.

Kan man forutsi farlighet? LL viser til 'naturlig eksperiment'-unders $\varnothing$ kelser hvor antall falske positive var 2 av 3 . Til tross for slik usikkerhet spør myndighetene etter denne tjenesten. For å komme eventuelle utøvere til unnsetning kan man flytte argumentasjonen og fortelle at treff ved forutsigelse på andre områder er enda lavere. Så man har selskap med andre, om enn ganske slett selskap. Jeg tror LL glemte noe i farten, nemlig 
at de andre forutsigelsesområdene får langt mindre dramatiske følger for klienten enn det å kalles farlig.

Men LL har tro på å bedre de instrumentene som er, på nye tester fra andre land (HCR20 kombinert med PCL-R). Jeg kan forstå at det er noe fascinerende med tester som leder frem til en diagnose, en stadfesting av hva personen 'er'. Men straks den tanken er tenkt, melder en neste seg: hva er en diagnose om ikke annet enn en merkelapp, en betegnelse på en slags idealtype. Så hvordan er forholdet mellom diagnosen og virkeligheten, til mennesker i all sin mangfoldighet? Vi bruker karakteristikker på hverandre i dagliglivet, men forskjellen fra diagnoser er at de ikke inngår i et så maktsterkt system som rettspsykiatrien er. LL tar ikke opp slike spørsmål. De nye testene har en høy prediksjonsevne, sier LL, men han sier ikke mer om hva det betyr. Han argumenterer for de nye testene ved å si at det må sees som et rettssikkerhetskrav å bli vurdert om man er farlig innenfor omtrent samme ramme. Spørsmål om lik behandling blir ansett som viktig i juridisk sammenheng, ikke i helsevesenet. Her er det den enkeltes sykdom som avgjør hva som er relevante rammer for vurdering. Men i rettspsykiatriens blandingsverden kan medisinen støtte seg på jussens argumenttype.

Man sitter igjen med inntrykk av at hvis det fins et klart og uavhengig rettspsykiatrisk fundament, er det vanskelig å få øye på. Også rettspsykiatrien er innvevd i sine omgivelser og lener seg på dem, der den kan.

En praktisk ting: flere av referansene i teksten fins ikke i litteraturlisten.

3) Britta Kyvsgaard (BK) skriver om Motsättningarnas kriminalpolitik. Pendling mellan defensiv och offensiv modell, samtidig som hun også tar del i den kriminalpolitiske diskusjonen. Første tema er den rastløse kriminalpolitikken, som en flyvende hollender dømt til evig uro, flakker den fra det ene til det andre: Kriminalpolitiken har inte valt sida. Den pendlar mellan en defensiv och en offensiv modell (s. 38). Den defensive legger vekt på rettssikkerhet og moralske krav, mens den offensive ser straff som middel til å løse samfunnets problem. Fins det ingen mulighet for at kriminalpolitikken skal kunne slå seg til ro, noe nytt som kan redde den, spør leseren kanskje. BK levner lite håp om det, nye straffer handler om det samme, om å frata folk tid eller penger. Fra 1992 aner man en smal strime av en soloppgang (figur 1): samfunnstjeneste, som ikke er så ny likevel, for fortsatt handler det om å frata folk deres normale frihet. Dessuten blir den knapt brukt.

Med dette er diskusjonen om den urolige kriminalpolitikken ute av BKs historie. Før den forsvinner er det fristende å sende med en kommentar: Uro og svingninger i kriminalpolitikken henger kanskje først og fremst sammen med våre forhåpninger til straffen, at vi ser den som et middel til å minske lovbrudd. Men dette er et mål den aldri kan nå. Hvis vi tok utgangspunkt $i$ at årsakene til lovbrudd er mye mer kompliserte enn at straff kan hindre dem, ville vi være mindre utsatt for stadig å sette i verk nye tiltak - som ikke nytter. Dessuten er straff vanskelig å bruke formålsrasjonelt fordi den også handler om moral, rettssikkerhet osv. Denne dobbeltheten kommer frem i diskusjoner, men ofte slik at det enkelte argumentet hentes frem der de passer med andre formål, ikke utfra hensynet til en helhetlig kriminalpolitisk diskusjon.

Det har vært endringer i forhåpninger til straffen fra 1970-tallet til i dag, fra optimisme når det gjelder å kunne forandre lovovertrederen, via tanken om at ingenting nytter, til igjen en tro på at det nytter likevel, iallfall overfor noen typer lovovertredere, som er 
kombinert med et humant argument: det kan mildne straffens lidelse. Men samtidig fins det en annen, restriktiv linje som går ut på å skille ut de såkalte negativt sterke fangene for å isolere dem. Ulike tendenser side om side, men begge er sterkt forankret $\mathrm{i}$ en formålsrasjonell tenkemåte.

Samtidig er det slik at selv om kriminalpolitikken har vært urolig, har danske fangetall vært stabile siden 1970-tallet, og det til tross for at de registrerte lovbruddene er doblet omtrent (figur 2). Hvorfor? Fordi kriminalpolitikken har vært styrt av tjenestemenn i en liberal ånd, sier BK. Men så, fra midten av 1990-tallet ble viljen til å straffe en annen og langt mer pågående, iallfall på områder som ble fanget inn av medienes lys. Nye sosiale hendelser, moderne tider, kan man si, med sine fragmenterte fremstillinger innhenter kriminalpolitikken. Hvordan skal den forsvare seg mot denne påvirkningen?

BK peker på mulige trekk ved den kriminalpolitiske fremtiden, blant annet at kriminalpolitikk blir politikk, også for danske sosialdemokrater som nå dreier i strengere retning; at offerorganisasjonene vil bli sterkere, nå er det de som med sine historier har overtatt for gjerningspersonene. Dette varsler hardere kriminalpolitiske tider. Men hvordan stemmer det med et nordisk, sosialdemokratisk ideal om likhet? Det stemmer ikke, derimot stemmer det med tendensen til større forskjeller og større aksept av forskjeller i levekår, som også slår inn i fengslene.

BK hekter ofrenes fremmarsj til det at vi alle kan føle oss som ofre i risikosamfunnet for eksempel for trusler om kjernekraft, sier BK og viser til Ulrick Beck. Og denne uroen for slike vage trusler overføres til lett synlige gjerningspersoner, som så må betale for vår overdrevne frykt med strengere straffer.

4) I artikkelen Lag \& ordning som vänsterprosjekt? Socialdemokratin och kriminalpolitiken satser Henrik Tham (HT) fra ett av punktene BK tok opp, at det er gått politikk i kriminalpolitikken. Han har skrevet om dette tidligere (Tham 1995), men det fortjener avgjort å tas opp igjen, med nye momenter.

HT beskriver hvordan sosialdemokratenes kriminalpolitikk har endret seg fra å være preget av pragmatisme, humanisme og tanken om rehabilitering, til å bli mer straffende og gir eksempler fra perioden 1994 til 1998. Hvordan kan dette forklares? spør HT. Det er ikke lett å si, for grunnene er langt fra åpenbare. Kanskje sosialdemokratene egentlig ikke ville dette, men ble tvunget av omstendighetene, av $\emptyset \mathrm{kt}$ (registrert) kriminalitet? Nei, HT viser at dette ikke holder. Men hva med at de oppfatter situasjonen som mer alarmerende, hauser opp antall lovbrudd slik de konservative har pleid, og også hauser opp sosiale problem? Slik kan det være, blant annet fordi mange av sosialdemokratenes støttespillere har arbeid i og dermed interesse av å opprettholde instanser som skal ta seg av dem som blir dyttet utenfor. Ett viktig punkt er at kriminalpolitikken er politisert, og HT gir flere grunner og eksempler som peker i retning av at den overtar som område for partipolitisk markering. Dessuten er de konservatives og sosialdemokratenes posisjoner på dette feltet delvis byttet om; sosialdemokratene trenger kriminalpolitikken som markeringsfelt mer enn de konservative gjør, fordi de har fordel av tendenser i tiden og hva som gjelder på 'det tilsynelatende amoralske markedet' (s. 108) hvor folk får som fortjent eller investert.

HT var den første, så langt jeg vet, som diskuterte kriminalpolitikken på denne måten, som så den som sosialt fenomen og forklarte oss hva som holdt på å hende: Den ble brått trukket frem i politikkens skarpe rampelys, og ble langt på vei en marionett styrt av andre 
tanker og diskusjoner enn hva som er fornuftig og rimelig reaksjoner på en person kjent skyldig i lovbrudd. På samme måte som rettspsykiatrien er også kriminalpolitikken innvevd i sin sammenheng og samtid. Interessant i seg selv, og dessuten viktig innsikt for den som skal delta i kriminalpolitiske diskusjoner. Kriminalpolitikken er blitt politikk og det er i denne sammenhengen de kriminalpolitiske argumentene skal prøve å klare seg.

5) Per Ole Träskman (POT) skriver om “En gemensam europeisk strafflag begränser nationell kriminalpolitik”. Et viktig og interessant tema, og såvidt jeg vet er det få i de nordiske landene som tar det opp. Men før vi kommer til denne annonserte hovedsaken, tar POT oss med på noen andre betraktninger som også er interessante: De lite alvorlige lovbruddene utgjør det største antallet, det er i kraft av sitt antall, som mengde, at de utgjør et samfunnsproblem. Likevel er kontrollapparatet henvist til å behandle dem en for en, med lover og rutiner som om de var alvorlige. Det kan ikke gå, og gjør det heller ikke. Systemet med sine ansatte vegrer seg for å behandle dem i sitt fulle omfang og finner ulike typer løsninger (administrative reaksjoner, av- eller nedkriminalisering osv). POT sier at alle handlinger må behandles likt, men blir de det, må de det? Hva med Thurman Arnold som i boka The symbols of government (1962) sier at dette er en illusjon, at det alltid er en hel del lovbrudd som aldri kommer for retten, det er bare en og annen gang de gjør det. Men det er helt tilstrekkelig i forhold til rettsapparatets grunnleggende oppgave, nemlig at vi nå og da feirer og opprettholder oss selv som rettsstat.

Man kan legge til at det også settes i gang andre tiltak enn de strafferettslige for å minske mengden av lite alvorlige lovbrudd gjennom informasjon, tekniske hjelpemidler osv. Dermed er handlingene løftet ut av det strafferettslige og moralske området og over i ett for det upraktiske og ubehagelige som vi vil unngå. Vi tar konsekvensen av det sosiologiske blikket om at det er som mengde de utgjør et problem, for samfunnet og for rettsapparatet. Kanskje vi også endrer oppfatning av det vi må betale, slik at det ikke lenger sees som bot for en synd, men som avgift, skatt på noen typer handlinger som er upraktiske, men som mange ikke ser som moralske brudd. Hva hender da? POT kommer tilbake til dette til slutt i artikkelen, og jeg tar det opp senere.

Den andre typen lovbrudd er de kvantitativt små, men kvalitativt alvorlige, som vold og drap. Problemet er, sier POT, at vi i vår oppfatning av lovbruddssituasjonen blander kortene og tror at de alvorlige forekommer i store mengder, slik de lite alvorlige gjør. Her er vår oppfatning av handlingen i takt med det rettsapparatet vi har bygget opp for å håndtere dem. Men det uheldige er at vi tror vi trenger mye mer kontroll.

Til tross for alle problemene som dagens kontrollapparat reiser, fins det noe enda verre: tenk om vi ikke brydde oss om å rangere handlinger og hendelser, om vi så alt som 'like ille' eller 'like lite ille'? Det fins en motsatt tendens til dette; blant annet internasjonal virksomhet som tar sikte på å bekjempe brudd mot humaniteten og menneskerettighetene. Nå er vi ved artikkelens hovedtema: tre typer internasjonal rettslig virksomhet.

i) Den internasjonale domstolen. POT beskriver den og de handlingene den er ment å ta opp, som ikke akkurat er umiddelbart aktuelle i Sverige. Likevel er de med, lagret som i et spisskammer, sier han, for å brukes i andre deler av verden. Men også det foregår i liten grad. Her kunne det en gang være interessant om strafferettsjurister diskuterte temaet $\mathrm{i}$ et litt bredere perspektiv, hvor den politiske dimensjonen var med: En internasjonal domstol er opprettet på toppen, over folks og delvis over nasjonale politikeres hoder. 
I nasjonal sammenheng sees (ideelt sett) domstolene som den tredje statsmakt, som sammen med parlament, regjering og presse holder den samlete makten i balanse. Og hvor den kriminalpolitiske diskusjonen ikke foregår altfor fjern fra det folket som skal utsettes for den. Hvordan kan folk få vært med på diskusjon og innflytelse på hva som skal regnes som folkemord eller etnisk rensing? Neste spørsmål er enda alvorligere: Hvorfor har vi Vest-Europa satset på domstol som med sin todelte avgjørelsesmulighet 'enten-eller' så ofte viser seg stivbent og hjelpeløs i innviklete og sammensatte konflikter hvor folk skal leve tett sammen, videre med resultatet. Hvorfor ikke bruke forhandlinger nå når vi begynner å få erfaringer fra både konflikter mellom enkeltpersoner og grupper (jf blant annet Johan Galtungs Transcend. Her står to ting sentralt: det gjelder at partene ikke mister ansikt, og det gjelder å tenke fremover: hvilken situasjon ønsker partene seg, hvordan komme dit, eller i nærheten, slik at alle får noe?) Med den internasjonale domstolen er kanskje Vesten enda en gang i bunn og grunn ute på sin egen egotripp. Dette styrkes av siste tids nyheter som er kommet lenge etter at POT skrev sin artikkel, nemlig at Kostunicha, i skrivende stund, ikke vil utlevere Milosevich, om han skal dømes skal det være i Serbia. Og humanitetens beskyttere overveier økonomiske sanksjoner for å få forbryteren stilt for egen domstol.

ii) Europakonvensjonen er også et internasjonalt innslag som har hatt nasjonal betydning. Men det ser ut til at den, i det vanlige spennet mellom effektivitet og rettssikkerhet, etterhvert har lent seg mer og mer mot det effektive, og dermed ikke lenger er med på å bevare rettssikkerhetsgarantier, slik den var.

iii) Enda en internasjonal hendelse er at $E U$ mer og mer overtar kriminalpolitikken, med krav om kriminalisering av fenomen som knapt nok fins i de tre nordiske EU-land. POT setter oss på sporet av viktige spørsmål som får sitt svar med Corpus-juris, et forslag om lover til forsvar for EUs finansielle interesser, egen påtalemyndighet og domstol for hele EU. Et embryo til en kommende felles europeisk straffelov, det er det det er, sier noen. POT beskriver EUs forslag til retningslinjer for straff. I mine øyne ser de ut til å ligne uhyggelig på det man i USA kaller 'sentencing tables'. Dette apparatet skal være overordnet nasjonalt strafferettslig nivå. Med et høyere straffenivå enn i Norden vil det føre til at straffene $\varnothing$ ker med 50-100\% sier POT. Og, kan man legge til, det vil føre til flere fanger. Hva som behøves er å vise nasjonal motstand, sier POT.

Utvekslingen går ikke bare fra utlandet til Sverige, men også den andre veien, med svensk eksport av ideologier. Før var det behandlingstanken, i dag er Sverige med på den bølgen som tror på økt bruk av straff: det er blitt et foregangsland når det gjelder kriminalisering av prostitusjon, det vil si av den som kjøper seksuelle tjenester og med tanken om 'straff som fortjent' (just desert), blant annet.

Det mest skremmende synes visst i følge POT å være hvis det moralske grunnlaget for reaksjoner forsvinner og alt oversettes til $\varnothing$ konomiske beregninger, hvis samfunnets utgifter legges til grunn for det en uvøren utøver må betale, og dette sprer seg fra strafferetten til livsstil. Det vil bety at for eksempel røykere og syklister må betale for den faren de utsetter seg selv og andre for. POT håper at det ikke blir slik, selv om det fins tendenser til det. Jeg er enig med POT, men lurer på om vi kanskje får dobbelt opp: både en langsom fremrykning av tanken om at vi må betale for at vi ikke tar vare på helsa og en større vekt på det moralske som grunnlag for straff, for strengere straffer. 
6) Hannu Takala (HT) skriver om oppdagelsesprosenten Ouppklarade brott \& spaningens etik. På vems uppdrag arbetar polisen? Det går nedover med oppklaringsprosenten. Ikke for alle lovbrudd, for noen blir anmeldt i samme øyeblikk som de oppdages, som når politiet får tak i en som omsetter rusmiddel. Men for lovbrudd som folk anmelder selv, er kurven dalende. Hva betyr dette, hva speiler det? Kanskje at politiet bruker for liten tid på etterforsking, og dermed at de trenger flere ressurser? Så var det ikke det heller, for $\varnothing \mathrm{kt}$ politi ser ut til å minske antall anmeldelser: forsikringslovbrudd ble med ett langt mer usikkert (så for så vidt førte økt etterforskningsinnsats til færre anmeldte og uoppklarte lovbrudd).

Her kan legges til at også det absolutte antallet uoppklarte lovbrudd går opp. Det har også antall anmeldelser og antallet oppklarte lovbrudd gjort inntil de siste årene (i Norge iallfall). Alt dette må sees i sammenheng.

Det handler ikke bare om mengde saker, men også om hvordan sakene blir sett og håndtert: HT er inne på dette når han viser til eksempler fra tidligere tider når en hendelse ikke ble anmeldt fordi klager og politiet fant ut at det hadde lite for seg. Kanskje dette er en hovedsak: at den $\varnothing$ kte prosenten uoppklarte lovbrudd først og fremst speiler et endret samfunn hvor det er lettere å abstrahere handlinger fra sin sosiale sammenheng ved å se dem som lovbrudd.

Likevel er det som vi tror på den synkende oppklaringsprosenten, at det er et problem at så få av de anmeldte handlingene oppklares, og umiddelbart leter etter metoder for å oppklare flere. HT diskuterer ikke dette, men tar opp forslag om nye etterforskingsmetoder og peker på det etisk betenkelige ved noen av dem, og det paradoksale ved andre, som provokasjon hvor politiet begår lovbrudd for å avdekke lovbrudd. Det er ikke noen ny metode. Provokasjon ble brukt like etter 2. verdenskrig for å avdekke ulovlig kjøp, for straks å bli opphevet fordi det stred mot viktige prinsipper. I dag brukes provokasjon. Så kanskje verdier og prinsipper ikke står så sterkt lenger blant myndighetene og i opinionen? Kanskje vi fanges av alle de tallene vi samler, av kurver og diagrammer vi tror forteller oss 'hvordan det er', av det praktiske, tekniske, elektroniske vi omgir oss med. Metode er innhold. Dette at vi plutselig har fått kapasitet til å registrere så mange, oppbevare og katalogisere, samle dem i tabeller og diagram har gitt oss mulighet til å skape helt bestemte bilder av virkeligheten. HT er inne på dette når han sier at våre forestillinger om organisert kriminalitet antar mytiske dimensjoner.

La oss følge den tanken HT er inne på tidligere: at hva som skal kalles lovbrudd er noe vi forhandler om, noe vi vurderer og bestemmer oss for: skal, skal ikke. Dette betyr at den mengden lovbrudd som registreres i et samfunn speiler hvordan vi velger å se handlinger, som igjen henger sammen med hvordan samfunnet er organisert. Lovbrudd er det vi velger å gå til politiet med. Vi anmelder det vi anmelder og straffer det vi straffer. Verken mer eller mindre. Burde vi oppklare eller straffe mer? Kanskje det. På hvilket grunnlag i så fall? For å få flere fanger? Eller sysselsatt flere som fangevoktere? Det er ikke slike argumenter som nevnes, men andre virkningsargumenter: at det ville bryte med folks rettsbevissthet, at folk ville slutte å stole på myndighetene. Straks vi snakker slik, er det som om vi tenker utfra at det fins en faktisk mengde kriminalitet, og av denne er det bare noe som registreres og av dette igjen, bare noe som blir straffet. Dette fremstår som et problem som automatisk får til svar at vi trenger mer politi.

Det er ikke vanskelig å $\emptyset$ ke antall anmeldelser, dømte og fanger, det er bare å organisere samfunnet slik at vi blir enda mer bekymret og redde, og så øke kontrollapparatets 
kapasitet, slik USA har gjort. Men det er slett ikke sikkert at oppklaringsprosenten vil gå ned, det er vanskelig å få til. Antakelig vil det forutsette at antall anmeldelser går ned. I så fall måtte vi organisere samfunnet slik at færre syntes de måtte anmelde hendelser til politiet.

Å ta utgangspunkt i oppklaringsprosenten slik HT har gjort, viste seg å åpne for interessante og grunnleggende diskusjoner, også om 'hva er kriminalitet'.

7) Peter Lindström (PL) tar opp liknende tema som både POT og Hannu Takala (HT) i artikkelen Innebär färre rapporteftergifter och åtalsunderlåtelser minskad brottslighet \& ökad trygghet? Hans utgangspunkt er at rettsvesenet har som mål å minske antall lovbrudd og øke tryggheten (som kanskje er helt forskjellige ting). For å få til det mener myndighetene at toleransen mot lovbrudd må minske og gå mot null. Og det de har valgt ut som aktuelt område, er å minske bruken av påtaleunnlatelse (åtalsunderlåtelse) og rapporteftergifter (at lovbruddet ikke rapporteres videre til påtalemyndigheten (s. 147)).

Fra 1980 til begynnelsen av 1990-tallet økte antall rapporteftergifter, som ble gitt først og fremst for butikktyveri. Fra 1990 og frem til 1995 sank antallet brått. PL diskuterer hva endringene kan komme av. Kanskje det var fordi lovbruddene var blitt alvorligere. Noen av dem er det, for antall voldslovbrudd blant unge har $\emptyset \mathrm{kt}$ i senere år, men dette er for få tilfeller til å forklare hele nedgangen. Heller ikke en regelendring slik at tilbakefall minsket muligheten for rapporteftergift, kan fullt ut forklare den brå nedgangen. Dette fremstår som enda et eksempel på at endringer i antall saker kontrollapparatet reagerer på, først og fremst skyldes kriminalpolitiske beslutninger. Hvilken betydning fikk endringene? PL viser at rapporteftergiftene ikke først og fremst beskyttet unge, 15-19åringer, mot tiltale, men eldre, de over 60 år. Og de økte sin andel tiltalte med $30 \%$ da rapporteftergiftene gikk ned. En annen følge er at stadig flere naskeri forblir uoppklart. $\mathrm{Og}$ at stadig flere unge tiltales - stikk motsatt tendensen i mange andre land.

Påtalemyndigheten kan gi påtaleunnlatelse, og gjør det fortsatt, men det er skjedd en endring slik at unge, 15-20-åringer sjeldnere får påtaleunnlatelse i 1998 enn ti år tidligere. Det gjelder særlig lite alvorlige lovbrudd, som naskeri. PL viser at antallet siktete 1517-åringer er doblet de siste ti årene. Det får også betydning for hvilke reaksjoner de unge møtes med. Økningen er særlig stor når det gjelder dom om overføring til sosialvesenet. Innebygget i teksten ligger spørsmålet om hvorfor ungdommer stilles for retten for å få denne reaksjonen, spesielt på bakgrunn av at Ungdomsbrottskomitéen advarte mot bruk av domstol for de yngste.

PL ser på hva slags lovbrudd unge er registrert for i en ti årsperiode og frem til i dag og finner at det er en øking i antall voldshandlinger, men både før og nå utgjør dette et relativt lite antall handlinger. Lovendring om at tilbakefall minsket muligheten for påtaleunnlatelse, kan heller ikke forklare hele $\emptyset$ kingen i tiltaler. Igjen er det endringer i det kriminalpolitiske klimaet som peker seg ut.

PL mener det er på tide å tenke på andre reaksjoner enn bruk av domstol: hva med bot for naskeri; mekling og da ikke parallelt med rettssak, slik det er i Sverige i dag, men som eneste oppfølging.

Hensynet til politi og rettsvesen spiller også inn: det er umulig å reagere på alle lovbrudd med tiltale og dom, politi og påtalemyndighet er nødt til å bruke den muligheten de har til skjønnsmessige vurderinger om ikke systemet skal bryte sammen. Men dette bryter mot påtaleplikten, et spørsmål som også Träskman og Takala har tatt opp. 
Det spørs om ikke et slikt dogmatisk krav som på taleplikt, må sees som en ideal fordring, i strid med en praktisk og fornuftig kriminalpolitikk, best egnet for kriminalpolitikkens Gregers Werle (i Henrik Ibsen: Vildanden), om noen vil påta seg en slik rolle.

8) Makt och maktlöshet. Kriminalpolitiken som styringsinstrument er tittelen på Laila Freivalds (LF) bidrag. Hun er justisminister og den eneste kriminalpolitikeren som deltar. Dermed er dette også skrevet i en annen tradisjon og skrivemåte. Vi er i et politisk landskap nå, med andre regler for hva som kan sies og hvordan, og teksten bør vurderes på sine premisser som er andre enn kriminologiens. Ett tema hun er inne på er avveiingen mellom hensynet til effektivitet og humanitet og den enkeltes integritet, for eksempel i diskusjonen om etterforskningsmetoder. I avsnittet om forebygging av lovbrudd nevner hun at det var vanskelig for noen å bruke kriminalpolitisk syn på det som foregår i skole, sosialvesen og næringsvirksomhet. Jeg vil si at man burde lytte til at dette blir sett som vanskelig, for våre skandinaviske samfunn kan bli svært opphengt i middel-mål-tenking, og i kriminalitetsbekjempelse. Men skal vi forankre det å tilegne seg kunnskap og innsikt, hjelp og arbeid i noe så snevert som kriminalitetsbekjempelse, når det handler om store og viktige spørsmål og tema; virksomheter som også er mål i seg selv? LF går inn for at kriminalpolitikken ikke er blitt mer repressiv, generelt sett. Andre artikler i boka gir grunnlag for å si at den på noen områder faktisk er blitt det.

\section{Hedda Giertsen \\ Institutt for kriminologi og rettssosiologi Universitetet i Oslo}

Mike Presdee: Cultural Criminology and the Carnival of Crime. Routledge, London and New York, 2000, $182 \mathrm{~s}$.

Presdees lille bok tar for seg noen store tema. Den søker å forstå og analysere utbredelsen og opptattheten av "meningsløs" vold, hat, fornedrelse og ondskap i det postmoderne samfunn. Man kommer ingen vei ved å stemple slike handlinger som ondskap, i stedet er det Cultural Criminology som trengs for å kunne oppnå forståelse for det "meningsløse". Dette kan virke bra, men spørsmålet er selvsagt hva Presdee sikter med bruken av begrepet Cultural Criminology. Det presenteres vi ikke for noe sted så vidt jeg kan se. Den samme mangel på analytisk begreps avklaring slår en gang på gang under lesningen av boka.

For Presdee er begrepet "the Carnival of Crime" helt sentralt. Et kapittel på 25 sider vies også karneval begrepet og denne institusjonens utvikling opp gjennom historien. Karnevalet (betyr egentlig farvel til kjøttet) har alltid hatt en grenseoverskridende funksjon. Det var en anledning til å snu tingenes orden på hodet, menn kledde seg som kvinner, tjenere opptrådte som herrer og så videre. Det var en kort konsentrert periode, oftest en religiøs høytid, hvor man slapp kaos løs. Presdee hevder at det postmoderne samfunn er preget av karneval, at det har blitt en del av den postmoderne kultur. Det finnes elementer av karneval i TV shows (Spitting image) og i populær kulturen (S\&M, rave parties, tatovering, piercing, ekstrem sporter og så videre). Vi trenger karneval for å kunne holde ut presset i det postmoderne samfunn hevder han. Men også kriminaliteten har fått klare trekk av karneval. Eksempler er "joy-riding", det vil si tyveri av biler hvor man er 
ute etter raske biler man kan kjøre i filler for siden ofte å "ofre" ved at man dumper dem eller setter fyr på bilene. Et annet eksempel han nevner er de store ulovlige demonstrasjonene mot WTO (World Trade Organization) som den i Seattle, som helt tydelig har preg av gateteater og karneval.

Presdee er tydeligvis selv fascinert av meningsløs vold, sado mascohisme og andre ekstreme uttrykk. Den vitenskapelige analysen kommer det dessverre ikke så mye ut av. Som studie av "meningsløs" vold havner den i skyggen av klassikere som Katz bok "Seductions of Crime" som gir et langt mer nyansert bilde og en bedre forståelse for disse handlingene. Presdee mangler definitivt Katzs unike evne til å leve seg inn i og gi en troverdig fremstilling av de forføreriske sidene ved verdens ondskap. Presdees fremstilling blir ikke verken teoretisk eller antropologisk dyptpløyende nok. Til tider virker det som han ønsker å skrive sin egen selvbiografi uten at denne på en tilstrekkelig måte kaster lys over de tema han tar opp til behandling.

Teoretisk sett er dette en merkelig bok. Den er utpreget fransk postmodernistisk, men samtidig preget av tradisjonell kritisk marxistisk kriminologi. Dette resulterer i en fremstilling som det ene øyeblikket flyr høyt oppe blant begrepene og symbolene sammen med de franske postmodernister, men som i neste øyeblikk er svært kritisk jordnær i forhold til det engelske samfunns utstøtningsmekanismer og marginaliseringen av arbeidsledig ungdom. Boka blir derved politisk og konkret det ene øyeblikket, opptatt av forførelse, symbolikk og karneval det neste. Fremstillingen halter derfor og mange av de tema han tar opp synes sære i et nordisk perspektiv.

Alt i alt er jeg ikke særlig begeistret for "Cultural Criminology". Den innfrir ikke hva den lover, den mangler antropologisk dybde og er heller ikke særlig spennende teoretisk sett. Bruken av karnevals analogien virker til tider noe påtatt og den tilfører analysen lite nytt. Jeg vil derfor anbefale de som er interessert i Presdees tema å lese andre fremstillinger, som Ferrell og Sanders "Cultural Criminology" og Katzs "Seductions of Crime" som gir en langt bedre forståelse og er mer dyptpløyende verker.

\section{Paul Larsson}

Politidirektoratet i Olso

Malin Åkerström \& Ingrid Sahlin (red.): Det motspänstiga offret. Lund: Studentlitteratur 2001. 289 sider.

Ifølge indledningen til denne antologi vil bidragyderne problematisere begrebet "offer". Redaktørerne beskriver formålet således (s. 7):

Vi vill undersöka vad föreställningar om offer betyder. Beteckningen antas vara socialt producerad; i samtal, filmer, berättelser och lagtexter används bilden av offerskap på olika sätt. Yrkesutövare, frivilligarbetare på brottsoffer- och kvinnojourer, lagstiftare och de parter som är involverade i en konflikt som ges benämningen brott, kan således skapa sympati eller mobilisera fördömanden genom att t.ex. understryka eller nedtona ansvar, lidande eller det behjärtansvärda.

Titlen på bogen: "Det motspänstiga offret" (det genstridige offer) hænger sammen med, at offerrollen ikke er entydigt attraktiv. I indledningen sammenfattes det som følger (s. 21):

Flera av kapitlen behandlar ett motstånd mot att själv tillskrivas eller anamma en offeridentitet. Denna implicerar ju skyddsbehov och värnlöshet. Människor tycks ha en 
grundläggande önskan inte enbart om sympati för lidande - utan också om att ses som kompetenta, visa att de kontrollerar sitt liv och få respekt.

Bogen består af fire dele. Første del om billeder af offeret indeholder - foruden et genoptryk af Nils Christies kendte artikel fra 1986 om "det ideelle offer" - et kapitel af Henrik Tham, der bl.a. beskriver, hvordan et stort antal offerorganisationer er opstået i Sverige siden 1990, hvordan viktimologien som særligt forskningsområde ekspanderede fra omkring 1970, hvorfor "Sexualbrottsutredningen" (SOU 1976:9) udløste et ramaskrig i Sverige, og hvordan den voksende interesse for "forbrydelsens ofre" kan forklares. Det påpeges for eksempel (s. 34), at "[S]åvel det politiska högern som vänstern använder brottsoffret i krav på kriminaliseringer och straffskärpningar. Brottsoffret är i dag, till skillnad från för ett par årtionden sedan, politiskt gångbart.” Tham spørger, hvilken fremtid offeret vil få i kriminalpolitiken, og kan se tegn på ekspansion både til nye typer af ofre og til flere rettigheder for ofre, men også tegn på en bevægelse i modsat retning: Hvis alle defineres som ofre, kan alle ikke hjælpes, og nogen $\emptyset$ nsker slet ikke dette stempel. Tham slutter dette udmærkede kapitel som følger (s. 41):

Något av en paradox uppstår. Den fortgående individualiseringen i ett alltmer marknadspräglat samhälle ger upphov till en motsatt tendens. Samhällets atomisering leder till en känsla av otrygghet och utsatthet och föder behov av samhörighet, meningsfullhet och kollektiva projekt. I identifieringen med och empatien för brottsoffret erbjuds en gemenskap. Detta behov exploateras sedan av massmedier, politiker och andra intressegrupper. Brottsofferperspektivet utvidgas ytterligare och förstärker sig självt. Den politiska utvecklingen av brottsoffret kommer ytterst att bestämmas av statens och den allmänna politikens behov av konsensus.

Bogens anden del om offerbilleder som sociale redskaber ("verktyg") består af et kapitel om kvindemishandling som kundskabsfelt (Berit Andersson og Magnus Lundberg), et kapitel om mishandlede kvinders opbrud og modstand (Margareta Hydén) og et kapitel om ældre mennesker som ofre for vold og andre forbrydelser (Håkan Jönson). Det første af disse tre kapitler anlægger et konstruktivistisk perspektiv på kvindemishandling og viser, hvordan forskellige aktører, først og fremmest kvindebevægelsen og parallelt hermed "kvinnojourerna", har defineret problemet, men også, hvordan der foregår et magtspil om kundskabshegemoni og ekspertindflydelse. Der er en interessant sammenligning mellem den svenske offerdiskurs og Joel Bests (1997) beskrivelse af en generel offerideologi, og det hævdes, at kvinderne ikke altid kan se sig selv i lyset af diskursen og ideologien. Hvis en kvinde herefter ikke optræder i overensstemmelse med de herskende forestillinger om en mishandlet kvinde, kan det betyde, at hun mødes med mistro og afvisning.

På baggrund af ti kvinders beretninger om, hvordan og hvorfor de er brudt ud af voldelige ægteskaber, spørges der i det andet af disse kapitler, om mishandlede kvinders modstand er så allesteds nærværende, at den er svær at identificere både for omgivelserne og kvinderne selv, og om modstanden ofte er subtilt og indirekte udtrykt og ikke altid antager kulturelt forventede former. I modsætning til den sædvanlige mandlige krigermodel for modstand, der ikke har plads til ambivalens, kan ifølge Hydén kvinders modstand mod voldelige mænd ses som en proces, der ikke nødvendigvis indebærer direkte konfrontation med manden. Hvis man definerer modstand som aktive, velovervejede handlinger, kan kvinders måde at gøre modstand på, let blive defineret som ikke-modstand og en kvinde dermed bl.a. i en retlig proces blive betragtet som ikke-offer. Omvendt, hvis 
en kvinde synes at opfylde kriterierne som "rent" eller "ideelt" offer, risikerer hun "att stängas in i sitt lidandes historia och på så sätt för all framtid definieras av förövarens handlingar" (s. 115). Disse to kapitler om mishandlede kvinder giver stof til eftertanke.

Det tredje kapitel i afsnittet om offerbilleder som sociale redskaber indeholder en analyse af, hvordan problemet med vold og overgreb mod ældre beskrives i forskellige sammenhænge. Det knytter naturligt an til bl.a. Nils Chrisites begreb "det ideelle offer"og ser viktimisering af mennesker og grupper som et resultat af forhandlingsprocesser inden for forskellige praksisområder. Det viser sig ifølge Jönson (s. 145) "sammanfattningsvis att 'samhället' inte producerar entydiga bilder, utan snarare ett komplext spel av lokalt förankrade bilder og motbilder." En interessant konstatering er det, at opfattelsen af de ældre som ofre ( $\mathrm{fx}$ for vold) overskygger den kendsgerning, at nogle ældre også er gerningspersoner (fx til vold mod andre ældre). Dette står i modsætning til opfattelsen af ungdomsvold, hvor udgangspunktet er den unge voldsmand.

Bogens tredje del om ofre i tid og rum består af to kapitler. Det første om tiden som retorisk ressource (Anna Ryding) handler om "brottsofferjourerne" som frivillig organisation i en vis konkurrence med samfundets etablerede institutioner, deres insisteren på tid (og medmenneskelighed) som noget, de har mere af end de professionelle, og de begrænsninger, som de af forskellige grunde alligevel må sætte for tidsforbruget i forhold til ofrene. Der er forskel mellem retorik og virkelighed, mellem ideologi og praksis. Det andet kapitel om forbudte rum (Ingrid Sahlin) handler om interaktionen mellem parterne $i$ en situation, hvor den ene defineres som potentielt offer for den anden, og denne anden pålægges besøgsforbud. Det konkluderes, at opdelingen i (potentielle) ofre og (potentielle) krænkere er ufrugtbar set ud fra et præventivt synspunkt. Der er under alle omstændigheder en tilbøjelighed til, at begge parter betragter sig som ofre, men samtidig præsenterer sig som bevidste og effektivt handlende personer. Kapitlet slutter som følger (s. 216):

En förståelse av vad som sker mellan parterna i ett besöksförbud förutsätter därför en insikt om den relativa symmetrin i deras upplevelser av varandras handlingar och ett erkännande av att båda parter är aktörer.

Fjerde del af bogen består af tre meget forskellige kapitler sammenfattet under begrebet ofre uden for mønsteret ("mallen"). Det første kapitel handler om staten som offer med særstilling (Sven-Åke Lindgren), det andet beskriver, hvordan forretningsmænd advares mod at blive udsat for biltyveri i Polen (David Wästerfors), og det treje handler om Annie, der som mishandlet kvinde ikke benytter sig af den sædvanlige offerretorik, men tværtimod påtager sig et medansvar (Malin Åkerström). Annies "modberetning" og Åkerströms konklusion (s. 278), at "offer" ikke bare er en objektiv kategori, men afhængig af en social, moralsk produktion, understreger endnu engang, at bogens indfaldsvinkel - konstruktivistisk og interaktionistisk - er vigtig som korrektiv til den efterhånden udbredte brug af "hensynet til offeret" i såvel kriminalpolitik som offerbevægelser.

Beth Grothe Nielsen

Juridisk Institut, Aarhus Universitet 